\title{
A FACTOR ANALYSIS OF ATTITUDE OF EDUCATION FRATERNITY TOWARDS THE ROLE OF TECHNOLOGY IN EFFECTIVE LEARNING: AN EMPIRICAL STUDY IN HIGHER EDUCATION INSTITUTION
}

\begin{abstract}
Use of Technology is empowering teachers and students, and enhancing teaching and students ' achievement which has been highlighted in several studies. Well planned lessons integrating technology are often more engaging, memorable and inspiring to students (Tornabene, 1998). Attitudes refer to one's positive or negative judgment about a concrete subject. Attitude is a major predictor of future use of technology. Student teachers have positive attitude and are highly enthusiastic about interactive whiteboards as an important feature of teaching and learning, and this motivated them to practice using the technology (Kennewell, \& Morgan, 2003).

The purpose is to create new opportunities in teaching and learning by integrating computer, multimedia, and network technologies. However, it is not clear whether use of this new technology will automatically result in effective learning or make students dependent on technology to learn. Will Students use Technology appropriately? The same doubts prevailed with the invention of the printing press, radio, and television. All of them have positively contributed in access to information that can be transformed into knowledge and wisdom thereafter. Proper use of technology can become an effective tool to enhance learning. This research is an attempt in understanding the attitude of teachers as well as students towards the role of technology in higher education.

The study is based on primary data collected through a sample size of 130 units consisting of 100 students and 30 teachers from universities located in NCR, India. Factor analysis has been conducted to measure the attitude of the teachers and the students. The study was been conducted in NCR, India and leaves the scope of further research in Higher Education across the globe.
\end{abstract}

Keywords: attitude, technology, career advancement, learning facilitator, factor analysis

\section{INTRODUCTION}

Today technology is evolving at a reckless pace. The rate of change is such that one does not get to experience the same aspect of technology twice in couple of years, it becomes obsolete by that time. Within the past decade, Technology has completely changed the ways we learn, interact and virtually 'experience' things. Information and communication technology (ICT) has also brought a paradigm shift in the approach towards learning and education. Teaching and instructional aids today include the use of power point presentations, instructional DVD's, animated motion pictures etc. Govindasamy (2002) and Khan (2000) pointed out that Classroom Technology is the collection of software, hardware and, processes that facilitate learning (and teaching) and thus impact (mostly positively) the learner's attitude and performance. These 
technological changes have obligated universities to respond in novel and creative ways that at times defy the traditional perceptions about how education should be delivered.

Ebijuwa (2005) defined ICT as tools used for collection, processing, storage, transmission, and dissemination of information. With advances in ICT, electronic information resources such as electronic books, electronic journals, CD-ROM databases, OPAC, Online databases and the Internet have launched the world into an information age. No institution or organization can still rely on only traditional printed information resource to perform effectively and efficiently. Manochehri and Young (2006) believe that technology facilitates project-based, cooperative, interdisciplinary, and thematic learning. Empowering learning environments with technology give students choice in their learning so that they can solve the problems with ease of correctional and rebuilding methods available through its application. This enables learning to become simpler and improves students' inventive thinking (e.g., problem solving) (Chief Executive Officer (CEO) Forum on Education and Technology, 2001) and makes them independent decision-makers. The power to undo and reconstruct encourages the students and teachers alike in experimenting with the newer aspects of problem solving.

Recent technological advancements have provided educators and learners with new tools to support in-class instruction and coursework. Sandholtz et al. (1997) suggested that the impact of technology on education has the potential to change education in a positive way if done under certain circumstances. Students use technology as a tool to collect, organize, and analyze data; to enhance presentations; to conduct simulations and to solve complex problems. These students began to respond positively to the alternate ways of expressing their knowledge, which not only raises their self-esteem but their status with the teachers and their peers. Hence, learning in digital space can lead to enhanced learning experience largely due to opening up of student's environment (Mun \& Hwang, 2003).

Coming on to more humane touch to technology, one requires understanding of basis meaning of Attitude - according to Simpson, Koballa, Oliver, and Crawley (1994), attitudes can be defined as specific feelings that indicate whether a person likes or dislikes something. Teacher attitudes toward technology may be conceptualized as teachers liking or disliking the use of technology. More positive attitudes towards the computer were associated with a higher level of computer experience (Dyck \& Smither, 1995; Teo, 2008a). Students' confidence on ICT can be explained through the attitude and behaviors of their teachers. Researchers from different parts of the world believe that the use of ICT tools for educational purposes depends upon the attitudes of teachers toward the technology (Albirini, 2004; Teo, 2008b).

Faculty work and roles within the academy have been reshaped and redefined by the integration of technology into the academic workplace (Baldwin 1998; Schuster and Finkelstein 2006). The study conducted by Sandholtz et al. (1997) on the Apple Classrooms of Tomorrow (ACOT) over a 10-year period shows changes in teacher and student interactions. Teacher peer sharing began to increase as students and teachers sought support from one another. Teachers began teaming and working across disciplines. Teachers and students started to show mastery of technology and started to integrate several kinds of media into lessons or projects. Student provided with technology-rich learning environments 'continued to perform well on standardized tests but were also developing a variety of competencies not usually measured. Negroponte, Resnick, and Cassell (1997) suggested that digital technologies can enable students to become more active and independent learners. The Internet will allow new "knowledgebuilding communities" in which children and adults from around the globe can collaborate 
and learn from each other. Computers will allow students to take charge of their own learning through direct exploration, expression, and experience. This shifts the student's role from "being taught" to "learning" and the teacher's role from "expert" to "collaborator" or "guide".

\section{THE AIM OF THE STUDY}

To research the attitudes towards the opportunity to integrate computer, multimedia, and network technologies in teaching and learning.

\section{MATERIALS AND METHODS}

Technology offers new ways of teaching and learning and has transformed the approach to student learning. Technology also provides a number of opportunities that would otherwise be difficult to create. Wilson (2001) envisions technology as offering endless possibilities to enhance educational experiences, expand academic opportunities, and develop critical employment skills. The increased ability to communicate with experts enhances students' learning process (Bransford, Brown, \& Cocking, 2000). When the learning experience is more relevant to the student, there is an increased level of individual student acceptance of information systems. Independence in learning (i.e., increased efficacy towards self managed and self-directed learning) is likely to occur (Compeaux, Higgins, \& Huff, 1999).

Romanov and Nevgi (2007) stated that students who utilized multimedia equipments were more energetic in using e-learning tools and achieved better course performance. Internet is credited with allowing access to a wide range of knowledge, especially as it has become central to scholarly communication through the creation of numerous e-journals and teaching resources (Leong \& Hawamdeh, 1999; Koubek \&Jandl, 2000; Thelwall, 2002; Rajab \& Baqain, 2005). Information and communication technology (ICT) has the potential to facilitate students' learning and improve teaching (Kazu \& Yavulzalp, 2008; Kirschner \& Woperies, 2003). Sharma (2009) identifies e-resources to include journals, e-mail, research reports, and bibliographic databases. Ibrahim (2004) adds library websites, online catalogues, and online reference works, while Aramide and Bolarinwa (2010), mention A-V resources, instructional audio tapes, instructional video tapes, VCD/DVD, radio, television, multimedia projectors, e-resources-electronic databases, e.g., JSTOR, e-documents, Internet/e-mail facility, CD-ROMS, computers, telephone facility (GSM/Landline), VSAT, printers, and digital cameras. Omotayo (2010), Thanuskodi (2010), Sharma (2009), Borrego (2007), and Ibrahim (2004) have all reported that e-journals are the most used among the arrays of available electronic resources. Tenopir (2003) analyzed that electronic resources have been rapidly adopted in academic spheres, though the behavior varies according to the discipline. Zakaria, Watson \& Edwards (2010) conducted their research on the use of Web 2.0 technology by Malaysian students. Result showed that students preferred using e-mail to disseminate and share digital contents. Similarly it was also found that for finding information related to education, students prefer to use search engines instead of asking friends or teachers. Use of technology as transformation has the potential to provide innovative educational opportunities (Hughes, 2005) by reorganizing students' cognitive processes and problem solving activities (Pea, 1985).

According to Hughes (2005), teachers need to have a technology-supported-pedagogy knowledge and skills base, which they can draw upon when planning to integrate technology into their teaching. Zhao, Pugh, Sheldon and Byers (2002) suggested “...teachers need to know the affordances and constraints of various technologies and how specific technologies might support their own teaching practices and curricular goals. They also need to know how to use technologies".

Coming to the deceiving part of technology, Plagiarism has always existed in education, including higher education, where it is one of the major forms of academic dishonesty. 
Assignments handed in by students may turn out to be copied from fellow students or to be taken over, in part or in whole, from existing published works. In a way, computers and the Internet only add to the means that students have at their disposal to commit plagiarism. However, they make it much easier to do and much harder to detect. As Austin and Brown (1999) have argued, plagiarism has become easier for students in two ways: "word processing programs allow students to easily "cut and paste" information from the Internet or other electronic media to develop a paper that appears to be original work" and "students' use of Internet information that may be unavailable in traditional sources makes documenting academic dishonesty more difficult to faculty." (Hinman,2002).

According to research by Patricia Greenfield (2009), UCLA distinguished professor of psychology and director of the Children's Digital Media Center, Los Angeles, Technology has played a bigger role in our lives but our skills in critical thinking and analysis have declined, while our visual skills have improved. As students spend more time with visual media and less time with print so they process information better. Most visual media are real-time media that do not allow time for reflection, analysis or imagination. Reading develops imagination, induction, reflection and critical thinking, as well as vocabulary but students today have more visual literacy and less print literacy. Although technology is not a panacea for all educational ills, technology is an essential tool for teaching.

\section{Data collection and Methodology}

In this study, two separate questionnaires were administered on the survey participants. Hence for the purpose of data collection, questionnaires were distributed among 125 students and 42 teachers from universities situated at NCR (National Capital Region), India using simple random sampling. Due to non-responsive error, total 130 (100 students and 30 teachers) responses were taken into consideration for further analysis.

Table 1. Taxonomy of survey indicators for Students

\begin{tabular}{|c|c|c|c|}
\hline Categories & $\begin{array}{l}\text { Survey } \\
\text { Item }\end{array}$ & Survey Statements for Students & References \\
\hline \multirow{12}{*}{$\begin{array}{l}\text { Technologi- } \\
\text { cal facility }\end{array}$} & TF 1 & I have phobia for ICT & Yusuf \& Balogun (2011) \\
\hline & TF 2 & Using technologies is stress busting. & Tabata \& Johnsrud (2008) \\
\hline & TF 3 & $\begin{array}{l}\text { The use of ICT improves the quality of communication between } \\
\text { faculty and students. }\end{array}$ & Yusuf \& Balogun (2011) \\
\hline & TF 4 & My self-image is enhanced by using technological innovations. & Tabata \& Johnsrud (2008) \\
\hline & TF5 & $\begin{array}{l}\text { Internet gives me flexibility to gather information at my } \\
\text { convenience. }\end{array}$ & $\begin{array}{l}\text { Lowther et al. (2003), } \\
\text { Sclater et al. (2006) }\end{array}$ \\
\hline & TF 6 & $\begin{array}{l}\text { Through internet I can get access to variety of learning } \\
\text { resources. }\end{array}$ & $\begin{array}{l}\text { Lowther et al. (2003), } \\
\text { Sclater et al. (2006) }\end{array}$ \\
\hline & TF 7 & $\begin{array}{l}\text { I have the accessibility to seek information using search } \\
\text { engines. }\end{array}$ & $\begin{array}{l}\text { Lowther et al. (2003), } \\
\text { Sclater et al. (2006) }\end{array}$ \\
\hline & TF 8 & I can gather information online if I happen to miss lectures. & Zakaria et al. (2010) \\
\hline & TF 9 & $\begin{array}{l}\text { I prefer to submit/take homework and assignments in electronic } \\
\text { form. }\end{array}$ & Austin \& Brown (1999) \\
\hline & TF 10 & It's easier to edit the assignments. & Austin \& Brown (1999) \\
\hline & TF 11 & $\begin{array}{l}\text { It's easy to access information through online/virtual library } \\
\text { than actual/real library. }\end{array}$ & Rajab\& Baqain (2005) \\
\hline & TF 12 & Internet gives me the facility to get connected to Experts. & $\begin{array}{l}\text { Bransford, Brown, \& } \\
\text { Cocking }(2000)\end{array}$ \\
\hline
\end{tabular}




\begin{tabular}{|c|c|c|c|}
\hline \multirow{13}{*}{$\begin{array}{l}\text { Role of } \\
\text { Technology } \\
\text { Effective } \\
\text { Learning }\end{array}$} & RE 1 & $\begin{array}{l}\text { Technology is producing decline in critical thinking and } \\
\text { analysis. }\end{array}$ & Greenfield (2009) \\
\hline & RE 2 & $\begin{array}{l}\text { Technology has lead to decline in deeper understanding of } \\
\text { information. }\end{array}$ & Greenfield (2009) \\
\hline & RE 3 & Technology in education enhances student's learning. & Yusuf \& Balogun (2011) \\
\hline & RE 4 & ICT gives opportunity to learn more. & Yusuf \& Balogun (2011) \\
\hline & RE 5 & Technology in education has made the course more interesting. & Yusuf \& Balogun (2011) \\
\hline & RE 6 & $\begin{array}{l}\text { The use of educational technologies provides richer educational } \\
\text { experience. }\end{array}$ & Yusuf \& Balogun (2011) \\
\hline & RE 7 & ICT increases instructional proficiency. & Yusuf \& Balogun (2011) \\
\hline & RE 8 & $\begin{array}{l}\text { Technology has the potential to provide innovative educational } \\
\text { opportunities. }\end{array}$ & Hughes (2005) \\
\hline & RE 9 & Information gathered from Internet is Authentic. & $\begin{array}{l}\text { Lowther et al. (2003), } \\
\text { Sclater et al. (2006) }\end{array}$ \\
\hline & RE 10 & $\begin{array}{l}\text { It is important to use new multimedia technologies to describe } \\
\text { projects. }\end{array}$ & Romanov \& Nevgi (2007) \\
\hline & RE 11 & $\begin{array}{l}\text { Use of new multimedia technology is essential for quality } \\
\text { education. }\end{array}$ & Romanov \& Nevgi (2007) \\
\hline & RE 12 & I learn more from ICT than I do from books. & Yusuf \& Balogun (2011) \\
\hline & RE 13 & Information gathered from internet is up to date. & $\begin{array}{l}\text { Lowther et al. (2003), } \\
\text { Sclater et al. (2006) }\end{array}$ \\
\hline
\end{tabular}

\section{Factor Analysis}

To find out the underlying structure of the data, factor analysis has been used. This has helped in finding out the important factors in terms of attitude towards role of technology in education and its usefulness in effective learning. Factor analysis has been separately applied for teachers' data and students' data.

\section{Factor Analysis of technological facility for Students}

Before applying the factor analysis, KMO and Bartlett test has been used to see the suitability of factor analysis for the data. A higher value of the test (.610) justifies the use of factor analysis.

Table 3 explains the total variance of the factors. The attribute have been divided into five factors as their Eigen value are greater than 1. The factors having Eigen values less than 1 have been ignored. The total variance explained by these four factors is 88.195 which is quite significant, thus it meets the requirement for the number of factors and their contribution rate as the criterion for variance analysis is that the total contribution rate should reach at least $80 \%$ (Chen, 2008).

Table 4 represents the rotated factor matrix which explains the correlation between the attributes and the related factor. The attributes have been divided into five factors based on their correlation values and hence each factor consists of those attributes having correlation greater than .65 (Wang, 2010). Factor 1 consists of flexibility, variety and easy accessibility. Factor 2 consists of using search engine, using online information and editing e-assignments. Factor 3 consists of connectivity to Experts. Factor 4 consists of enhanced self image, e-submissions and stress busting. Factor 5 consists of improved communication. Based on the attributes relating to the factors, the five factors have been named as Internet resourcefulness, Internet usefulness, Connectivity to Experts, Personal enrichment and Enhanced communication respectively. 
Table 2. Taxonomy of survey indicators for Teachers

\begin{tabular}{|c|c|c|c|}
\hline Categories & $\begin{array}{l}\text { Survey } \\
\text { Items }\end{array}$ & Survey Statements for Teachers & \\
\hline \multirow{10}{*}{$\begin{array}{l}\text { Career } \\
\text { Advancement }\end{array}$} & CA 1 & Using technology has good impact on my career. & Tabata \& Johnsrud (2008) \\
\hline & $\mathrm{CA} 2$ & I have phobia for ICT. & Yusuf \& Balogun (2011) \\
\hline & CA 3 & Using technologies is stress busting. & Tabata \& Johnsrud (2008) \\
\hline & CA 4 & Technology is important for conducting professional work. & Tabata \& Johnsrud (2008) \\
\hline & CA 5 & Resources are available to support technology needs. & Tabata \& Johnsrud (2008) \\
\hline & CA 6 & Institution recognizes those who use technology. & Tabata \& Johnsrud (2008) \\
\hline & CA 7 & $\begin{array}{l}\text { The use of ICT improves the quality of communication } \\
\text { between faculty and students. }\end{array}$ & Yusuf \& Balogun (2011) \\
\hline & CA 8 & $\begin{array}{l}\text { My self-image is enhanced by using technological } \\
\text { innovations. }\end{array}$ & Tabata \& Johnsrud (2008) \\
\hline & CA 9 & $\begin{array}{l}\text { Technology has the potential to provide innovative } \\
\text { educational opportunities. }\end{array}$ & Hughes (2005) \\
\hline & CA 10 & $\begin{array}{l}\text { The good use of educational technologies should be } \\
\text { recognized and reimbursed by the Institution. }\end{array}$ & Finley \& Hartman(2004) \\
\hline \multirow{13}{*}{$\begin{array}{l}\text { Technology } \\
\text { for Effective } \\
\text { Learning }\end{array}$} & TL 1 & $\begin{array}{l}\text { Students have become less attentive in class since everything } \\
\text { is available online. }\end{array}$ & Experts Opinion \\
\hline & TL 2 & $\begin{array}{l}\text { Technology is producing decline in critical thinking and } \\
\text { analysis. }\end{array}$ & Greenfield (2009) \\
\hline & TL 3 & $\begin{array}{l}\text { Plagiarism has increased since it's easier to edit the } \\
\text { assignments. }\end{array}$ & Austin \& Brown (1999) \\
\hline & TL 4 & Discipline is hampered with the use of technology. & Experts Opinion \\
\hline & TL 5 & ICT increases instructional proficiency. & Yusuf \& Balogun (2011) \\
\hline & TL 6 & Information gathered from Internet is Authentic. & \begin{tabular}{|l|} 
Lowther et al. (2003), \\
Sclater et al. (2006) \\
\end{tabular} \\
\hline & TL 7 & $\begin{array}{l}\text { Through internet I can get access to variety of learning } \\
\text { resources. }\end{array}$ & $\begin{array}{l}\text { Lowther et al. (2003), } \\
\text { Sclater et al. (2006) }\end{array}$ \\
\hline & TL 8 & $\begin{array}{l}\text { I prefer to seek information using search engines (e.g., } \\
\text { Google). }\end{array}$ & $\begin{array}{l}\text { Lowther et al. (2003), } \\
\text { Sclater et al. (2006) }\end{array}$ \\
\hline & TL 9 & $\begin{array}{l}\text { I prefer collecting homework and assignments in electronic } \\
\text { form. }\end{array}$ & Experts Opinion \\
\hline & TL 10 & $\begin{array}{l}\text { Use of new multimedia technology is essential for quality } \\
\text { education. }\end{array}$ & Romanov \& Nevgi (2007) \\
\hline & TL 11 & $\begin{array}{l}\text { It's easy to access information through online/virtual library } \\
\text { than actual/real library. }\end{array}$ & Rajab \& Baqain (2005) \\
\hline & TL 12 & Information gathered from internet is up to date. & $\begin{array}{l}\text { Lowther et al. (2003), } \\
\text { Sclater et al. (2006) }\end{array}$ \\
\hline & TL 13 & $\begin{array}{l}\text { My teaching pedagogy has been positively transformed due } \\
\text { to technology support. }\end{array}$ & Hughes (2005) \\
\hline
\end{tabular}

Table 3. The variance contribution and contribution rate of dominant component factor

\begin{tabular}{|c|c|c|c|}
\hline Component & $\begin{array}{c}\text { Variance } \\
\text { Contribution }\end{array}$ & $\begin{array}{c}\text { Contribution Rate } \\
(\%)\end{array}$ & $\begin{array}{c}\text { Accumulated Contribution Rate } \\
(\%)\end{array}$ \\
\hline 1 & 3.185 & 23.225 & 23.225 \\
\hline 2 & 2.695 & 20.413 & 43.638 \\
\hline 3 & 2.454 & 17.220 & 60.858 \\
\hline 4 & 1.923 & 15.023 & 75.881 \\
\hline 5 & 1.735 & 12.314 & 88.195 \\
\hline
\end{tabular}


Table 4. Rotated Component Matrix ${ }^{a}$

\begin{tabular}{|l|r|r|r|r|r|}
\hline \multicolumn{1}{|c|}{ Statements } & \multicolumn{3}{|c|}{ Component } \\
\cline { 2 - 5 } & 1 & 2 & 3 & 4 & 5 \\
\hline 6 The use of ICT improves the quality of communication between faculty & .030 & .012 & .107 & .042 & .920 \\
and students. & & & & & \\
7 My self-image is enhanced by using technological innovations. & .426 & .015 & -.113 & .692 & .097 \\
9 Internet gives me flexibility to gather information at my convenience. & .745 & -.071 & .029 & -.080 & .080 \\
11 Through internet I can get access to variety of learning resources. & .606 & .418 & -.338 & .189 & -.064 \\
12 I have the accessibility to seek information using search engines. & .391 & .729 & -.054 & -.132 & .110 \\
14 I can gather information online if I happen to miss lectures. & -.181 & .563 & .438 & .062 & -.126 \\
15 I prefer to submit/take homework and assignments in electronic form. & -.159 & -.001 & .411 & .632 & -.335 \\
18 It's easier to edit the assignments. & -.035 & .750 & .120 & .155 & .024 \\
19 Its easy to access information through online/virtual library than actual/ & .575 & .192 & .482 & .100 & -.076 \\
real library. & & & & \\
21 Internet gives me the facility to get connected to Experts. & .048 & .093 & .821 & -.056 & .147 \\
22 Using technologies is stress busting. & -.366 & .245 & -.172 & .585 & .316 \\
\hline
\end{tabular}

\section{Factor Analysis of Effective Learning through technology for Students}

Before applying the factor analysis, KMO and Bartlett test has been used to see the suitability of factor analysis for the data. A higher value of the test (.621) justifies the use of Factor analysis.

Table 5 explains the total variance of the factors. The attribute have been divided into four factors as their Eigen value are greater than 1. The factors having Eigen values less than 1 have been ignored. The total variance explained by these four factors is 87.506 which is quite significant.

Table 5. The Variance contribution and contribution rate of dominant component factor

\begin{tabular}{|c|c|c|c|}
\hline Component & Variance contribution & Contribution rate & Accumulated contribution rate (\%) \\
\hline 1 & 3.170 & 25.997 & 25.997 \\
\hline 2 & 2.734 & 23.764 & 49.761 \\
\hline 3 & 1.999 & 20.536 & 70.297 \\
\hline 4 & 1.453 & 17.209 & 87.506 \\
\hline
\end{tabular}

Table 6 represents the rotated factor matrix which explains the correlation between the attributes and the related factor. The attributes have been into four factors based on their correlation values and hence each factor consists of those attributes having correlation greater than .65. Factor 1 consists of enhanced learning, more opportunity, interesting and innovative. Factor 2 consists of instructional proficiency, authentic and up to date information. Factor 3 consists of better than books and richer experience. Factor 4 consists of describing projects and quality education. Based on the attributes relating to the factors, the four factors have been named as Enriched Learning, Learning Expertise, Superior Learning and Learning with Multimedia respectively. 
Table 6. Rotated Component Matrix ${ }^{a}$

\begin{tabular}{|c|c|c|c|c|}
\hline \multirow[t]{2}{*}{ Statements } & \multicolumn{4}{|c|}{ Component } \\
\hline & 1 & 2 & 3 & 4 \\
\hline 1 Technology in education enhances student's learning. & .751 & -.188 & .129 & .186 \\
\hline 2 ICT gives opportunity to learn more. & .660 & .343 & -.200 & .051 \\
\hline 3 Technology in education has made the course more interesting. & .580 & .293 & .098 & -.111 \\
\hline 4 The use of educational technologies provides richer educational experience. & .130 & .097 & .469 & .144 \\
\hline 5 ICT increases instructional proficiency. & .351 & .553 & .143 & .138 \\
\hline 8 Technology has the potential to provide innovative educational opportunities. & .606 & -.033 & .439 & -.058 \\
\hline 10 Information gathered from Internet is Authentic. & -.082 & .808 & -.097 & .243 \\
\hline 16 It is important to use new multimedia technologies to describe projects. & .049 & .162 & .467 & .698 \\
\hline 17 Use of new multimedia technology is essential for quality education. & .024 & .131 & -.021 & .901 \\
\hline 24 I learn more from ICT than I do from books. & -.003 & .029 & .817 & .026 \\
\hline 25 Information gathered from internet is up to date. & .128 & 693 & .451 & -.042 \\
\hline
\end{tabular}

Factor Analysis of Technological facility in Effective Teaching for Teachers

Before applying the factor analysis KMO and Bartlett test has been used to see the suitability of factor analysis for the data. A higher value of the test (.600) justifies the use of Factor analysis.

Table 7 explains the total variance of the factors. The attribute have been divided into four factors as their Eigen value are greater than 1. The factors having Eigen values less than 1 have been ignored. The Total Variance explained by these four factors is 89.56 which is quite significant.

Table 7. The Variance contribution and contribution rate of dominant component factor

\begin{tabular}{|c|c|c|c|}
\hline Component & Variance Contribution & Contribution rate (\%) & Accumulated contribution rate (\%) \\
\hline 1 & 3.139 & 27.766 & 27.766 \\
\hline 2 & 2.860 & 23.668 & 51.434 \\
\hline 3 & 1.998 & 20.083 & 71.517 \\
\hline 4 & 1.734 & 18.043 & 89.560 \\
\hline
\end{tabular}

Table 8 represents the rotated factor matrix which explains the correlation between the attributes and the related factor. The attributes have been into four factors based on their correlation values and hence each factor consists of those attributes having correlation greater than .65. Factor 1 consists of variety of resources, accessibility to search engines and multimedia technology. Factor 2 consists of increased instructional proficiency and accessibility to virtual library. Factor 3 consists of authentic and up to date information. Factor 4 consists of collect e-assignments and teaching pedagogy. Based on the attributes relating to the factors, the four factors have been named as Internet Versatility, Teaching Proficiency, Internet Efficacy and Teaching Style respectively. 
Table 8. Rotated Component Matrix ${ }^{a}$

\begin{tabular}{|c|c|c|c|c|}
\hline & \multicolumn{4}{|c|}{ Component } \\
\hline & 1 & 2 & 3 & 4 \\
\hline 31 ICT increases instructional proficiency. & .121 & .909 & .221 & -.015 \\
\hline 36 Information gathered from Internet is Authentic. & .086 & .072 & .907 & .058 \\
\hline 37 Through internet I can get access to variety of learning resources. & .834 & .276 & -.018 & -.030 \\
\hline 38 I prefer to seek information using search engines (e.g. Google). & .857 & -.063 & .098 & .154 \\
\hline 41 I prefer collecting homework and assignments in electronic form. & -.010 & .010 & .357 & .843 \\
\hline 43 Use of new multimedia technology is essential for quality education. & .721 & .001 & .252 & .186 \\
\hline $\begin{array}{l}45 \text { Its easy to access information through online/virtual library than actual/real } \\
\text { library. }\end{array}$ & .007 & .865 & .061 & .171 \\
\hline 47 Information gathered from internet is up to date. & 265 & 408 & .737 & .234 \\
\hline 48 My teaching Pedagogy has been positively transformed due to technology support. & 309 & 184 & -.087 & .823 \\
\hline
\end{tabular}

\section{Factor Analysis of Technological facility in Career Advancement for Teachers}

Before applying the factor analysis KMO and Bartlett test has been used to see the suitability of factor analysis for the data. A higher value of the test (.560) justifies the use of Factor analysis.

Table 9. explains the total variance of the factors. The attribute have been divided into four factors as their Eigen value are greater than 1. The factors having Eigen values less than 1 have been ignored. The Total Variance explained by these four factors is 87.755 which is quite significant.

Table 9. The Variance contribution and contribution rate of dominant component factor

\begin{tabular}{|c|c|c|c|}
\hline Component & Variance Contribution & Contribution Rate (\%) & Accumulated contribution Rate (\%) \\
\hline 1 & 3.020 & 26.753 & 26.753 \\
\hline 2 & 2.761 & 25.014 & 51.767 \\
\hline 3 & 2.027 & 19.586 & 71.353 \\
\hline 4 & 1.732 & 16.402 & 87.755 \\
\hline
\end{tabular}

Table 10 represents the rotated factor matrix which explains the correlation between the attributes and the related factor. The attributes have been into five factors based on their correlation values and hence each factor consists of those attributes having correlation greater than .65. Factor 1 consists of improved communication and innovative opportunities. Factor 2 consists of professional importance, enhanced self image and availability of resources. Factor 3 consists of impact on career and reimbursement. Factor 4 consists of recognition for using technology. Based on the attributes relating to the factors, the four factors have been named as Career Potential, Professional Significance, Professional Appreciation and Professional Recognition respectively. 
Table 10. Rotated Component Matrix ${ }^{a}$

\begin{tabular}{|c|c|c|c|c|}
\hline & \multicolumn{4}{|c|}{ Component } \\
\hline & 1 & 2 & 3 & 4 \\
\hline 27 Technology is important for conducting professional work. & .470 & .671 & .048 & -.297 \\
\hline 28 Resources are available to support technology needs. & .140 & .791 & .142 & .172 \\
\hline 29 Institution recognizes those who use technology. & .024 & .174 & .040 & .922 \\
\hline $\begin{array}{l}32 \text { The use of ICT improves the quality of communication between faculty and } \\
\text { students. }\end{array}$ & .761 & .115 & .058 & -.042 \\
\hline 33 My self-image is enhanced by using technological innovations. & -.123 & .798 & -.256 & 217 \\
\hline 34 Technology has the potential to provide innovative educational opportunities. & .872 & .026 & -.041 & .117 \\
\hline $\begin{array}{l}35 \text { The good use of educational technologies should be recognized and reimbursed by } \\
\text { the Institution. }\end{array}$ & .272 & .021 & .826 & .285 \\
\hline 30 Using technology has good impact on my career. & -.388 & -.072 & .742 & -.349 \\
\hline
\end{tabular}

\section{CONCLUSION AND RESEARCH IMPLICATIONS}

Thus from this study, the factors obtained for ICT facility to Students are Internet resourcefulness, Internet usefulness, Connectivity to Experts, Personal enrichment and Enhanced communication which indicates that students have an inclination for high tech equipments which eases their endeavor . Enriched Learning, Learning Expertise, Superior Learning and Learning with Multimedia factors were deducted for effective learning experience for students which shows that students find ICT as a useful tool in order to enhance their learning process. For career advancement of teachers, factors obtained were Career Potential, Professional Significance, Professional Appreciation and Professional Recognition and for effective teaching experience, Internet Versatility, Teaching Proficiency, Internet Efficacy and Teaching Style factors were deducted. Teachers also find use of technology supportive in their career enhancement and in effective teaching.

Hence, it can be concluded on the basis of the above mentioned factors that the communication between the students and teachers might improve with use of ICT. With Educational technologies, students might find their learning enriched and performances enhanced. Teachers might also find use of technology professionally significant and proficient. Teachers might observe change in their teaching pedagogy. These conclusions can further be hypothesized for future researches.

This research throws light and captures the essence of effective use of technology in enhanced learning. Preparing students for real life in our technological and diverse world require the universities to make the teachers and students realize that role of technology can play in their effective learning process. This would encourage both to embrace emerging technology to enhance the scope of the learning in the limited time period of their course work. Through factor analysis, this paper has been able to provide real insights into the important factors for effective learning with the use of technology. Capturing and imbibing of the images through the use of ICT for faster and retentive learning may further encourage the educationists to include wider topics in the scope of learning that were otherwise considered beyond scope for the given learning stage. This may bring about a change in the scope and level of educational courses that can be considered with respect to time limitations. The universities can focus on the important factors in their curriculum. 


\section{REFERENCES}

Albirini, A. A. (2004). An exploration of the factors associated with the attitudes of high school EFL teachers in Syria toward information and communication technology. Unpublished thesis The Ohio State University.

Aramide, K.A., \& Bolarinwa, O.M. (2010). Availability and use of audiovisual and electronic resources by Distance Learning Students in Nigerian Universities: A case study of National Open University of Nigeria (NOUN), Ibadan Study Centre. Library Philosophy and Practice. Available: http://unllib.unl. $\underline{\text { edu/LPP/aramide-bolarinwa.htm }}$

Austin, M.J. \& Brown, L.D. (1999). 'Internet plagiarism: Developing strategies to curb student academic dishonesty,' The Internet and higher education 2:21-33.

Baldwin, R. C. (1998). Technology's impact on faculty life and work. In K. H. Gillespie (Ed.), The impact of technology on faculty development, life, and work: New directions for teaching and learning, 76 (pp. 7-21). San Francisco, CA: Jossey-Bass, Inc.

Borrego, A., (2007). Use and users of electronic journals at Catalan Universities: The results of a survey. Journal of Academic Librarianship. 33(1):Available from AGORA database http://www.agInternetwork.org

Bransford, J. D., Brown, A. L., \& Cocking, R. R. (2000). How people learn: Brain, mind, experience, and school. Washington, DC: National Academies Press.

CEO Forum on Education and Technology (2001). The CEO Forum school technology and readiness report: Key building blocks for student achievement in the 21st century. Retrieved May 10, 2006 from http:// www.ceoforum.org/downloads/report4.pdf

Chen, P. (2008): Applied Mathematical Statistics, Beijing: China Machine Press.

Compeaux, D. R., Higgins, C. A., \& Huff, S. (1999). Social cognitive theory and individuals reactions to computing technology: a longitudinal study. MIS Quarterly, 23(2), 145-158.

Dyck, J. L. \& Smither, J. A. (1995). Older adults' acquisition of word processing. The contribution of cognitive abilities and computer anxiety. Computer in Human Behavior, 12 (1), 107-199.

Ebijuwa, A.A. (2005). Information and Communication Technology in university libraries: The Nigeria experience. Journal of Library and Information Science 7(1\&2): 23-30.

Finley, L. \& Hartman, D. (2004). Institutional change and resistance: Teacher preparatory faculty and technology integration. Journal of Technology and Teacher Education, 12, 319-337.

Govindasamy, T. (2002). Successful implementation of e-learning pedagogical considerations. The Internet and Higher Education, 4, 287-299.

Greenfield, P. (2009). University of California - Los Angeles (2009, January 29). Is Technology Producing A Decline In Critical Thinking And Analysis? Science Daily. Retrieved October 22, 2012, from http:// www.sciencedaily.com/releases/2009/01/090128092341.htm

Hinman, L.M. (2002). 'The impact of the internet on our moral lives in academia,' Ethics and information technology 4: 31-35.

Hughes, J. (2005). The role of teacher knowledge and learning experiences in forming technology- integrated pedagogy. Journal of Technology and Teacher Education, 13(2), 277-302.

Ibrahim, A.E. (2004). Use and user perception of electronic resources in the United Arab Emirates University (UAEU). Libri 54:21-23.

Kazu, I. Y. \& Yavulzalp, N. (2008). An analysis of the primary school teachers' usage of instructional software. International Journal of Emerging Technologies, 3 (1), 45-53. 
Kennewell, S. \& Morgan, A. (2003, July). Student teachers' experiences and attitudes towards using interactive whiteboards in the teaching and learning of young children. Presented at the IFIP Working Groups 3.5 Conference: Young Children and Learning Technologies. UWS Parramatta. Retrieved 16 July 2007 from http://crpit.com/confpapers/ CRPITV34Kennewell1.pdf

Khan, B. H. (2000). A framework for web-based learning. Englewood Cliffs, NJ: Educational Technology Publications.

Kirschner, P. \& Woperies, I. G. J. H. (2003). Pedagogic benchmarks for information and communication technology in teacher education. Technology, Pedagogy and Education, 12 (1), 127-149.

Koubek, A., \& Jandl, M. (2000). Diversified use of ICT in education. Campus-Wide Information Systems, 17(5), $161-166$.

Leong, S., \& Hawamdeh, S. (1999). Gender and learning attitudes in using web-based science lessons. Information Research, 5(1), Retrieved: January 12, 2004, from: http://informationr.net/ir/5-1/paper66. $\underline{\mathrm{html}}$

Lowther, D. L., Ross, S. M., \& Morrison, G. M. (2003). When each one has one: The influences on teaching strategies and student achievement of using laptops in the classroom. Educational Technology Research and Development, 51(3), 23-44.

Manochehri, N., \& Young, J. (2006). The impact of student learning styles with web-based learning (WBL) or instructor-based learning (IBL) on student knowledge and satisfaction. The Quarterly Review of Distance Education, 7(3), 313-316.

Mun, Y. Y., \& Hwang, Y. (2003). Predicting the use of web-based information systems: Self-efficacy, enjoyment, learning goal orientation, and the technology acceptance model. International Journal of HumanComputer Studies, 59, 431-449.

Negroponte, N, Renick, M., \& Cassell, J. (1997). Creating a learning revolution. Retrieved on 24 July 2001. Available: http://education.unesco.org/unesco/educprog/lwf/doc/portfolio/opinion8.htm

Omotayo, B.O. (2010). Access, use, and attitudes of academics toward electronic journals: A case study of Obafemi Awolowo University, Ile Ife. Library Philosophy and Practice. Available: http://unllib.unl.edu/ $\underline{\text { LPP/omotayo.htm }}$

Pea, R. D. (1985). Beyond amplification: Using the computer to reorganize mental functioning. Educational Psychologist, 20(4), 167-182.

Rajab, L., \& Baqain, Z. (2005). Use of information and communication technology among dental students at the University of Jordan. Journal of Dental Education, 69(3), 387-398.

Romanov, K., \& Nevgi, A. (2007). Do medical students watch video clips in eLearning and do these facilitate learning? Medical Teacher, 29(5), 490-494.

Sandholtz, J., Ringstaff, C., \& Dwyer, D. (1997). Teaching with technology: creating student-centered classrooms. New York: Teachers College Press.

Schuster, J. H., \& Finkelstein, M. J. (2006). The academic faculty: The restructuring of academic work and careers. Baltimore, MD: The Johns Hopkins University Press.

Sclater, J., Sicoly, F., Abrami, P. C., \& Wade, C. A. (2006). Ubiquitous technology integration in Canadian public schools: Year one study. Canadian Journal of Learning and Technology, 32(1), 9-33.

Sharma, C. (2009). Use and impact of e-resources at Guru Gobind Singh Indraprastha University (India): A case study. Electronic Journal of Academic and Special Librarianship 10(1): 3-8.

Simpson, R. D., Koballa, T. R. Jr., \& Oliver, J. S., \& Crawley, F. E. (1994). Research on the affective dimensions of science learning. In D. White (Eds.), Handbook of research on science teaching and learning. (pp. 211-235). New York: Macmillan. 
Tabata, L. N. \& Johnsrud, L. K. (2008). The Impact of Faculty Attitudes toward Technology, Distance Education, and Innovation. Res High Educ ,49, 625-646

Tenopir, C. (2003). Use and users of electronic library resources: An overview and analysis of recent research studies. Council on Library and Information Resources. Available: http://www.clir.org/pubs/reports/ pub120.pdf.

Teo, T. (2008a). Assessing the computer attitudes of students: An Asian perspective. Journal of Computers in Human Behaviour, 24, 1634-1642.

Teo, T. (2008b). Pre-service teachers' attitude towards computer use: A Singapore survey. Australian Journal of Educational Technology, 23(4), 413-424.

Thanuskodi, S. (2010). Use of Internet and electronic resources for medical science information: A case study. Journal of Communication 1(1): 27-4

Thelwall, M. (2002). Evidence for the existence of geographic trends in university Website interlinking. Journal of Documentation, 58(2), 563-574.

Tornabene, L. (1998). The SMART Classroom verses the traditional classroom: What the students are saying. 1-11. Retrieved July 1, 2006 from http://eric.ed.gov/ERICWebPortal/contentdelivery/servlet/ ERICServlet?accno=ED421963

Wang, L. (2010): Multivariate Statistical Analysis: Model, Case and SPSS. Beijing: Economic Science Press.

Wilson, J. M. (2001). The technological revolution: Reflections on the proper role of technology in higher education. In P. G. Altbach, P. J. Gumport, \& D. B. Johnstone (Eds.), In defense of American higher education (pp. 202-226). Baltimore, MD: Johns Hopkins University Press.

Yusuf, M. O. \& Balogun, M. R. (2011). Student-Teachers' Competence and Attitude towards Information and Communication Technology: A Case Study in a Nigerian University. Contemporary Educational Technology, 2(1), 18-36

Yusuf, M. O. (1998). A study of the dimensions of teachers' attitude towards computer education in Nigerian secondary schools. Journal of Computer Literacy, 2(1), 47-58.

Zakaria, M. H., Watson, J. \& Edwards, S. L. (2010). Investigating the use of Web 2.0 technology by Malaysian students. Multicultural Education \& Technology Journal 4(1): 17-29.

Zhao, Y., Pugh, K., Sheldon, S., \& Byers, J. L. (2002). Conditions for classroom technology innovations. Teachers College Record, 104(3), 482-515.

Research Scholar, M.S.Sc. (Psychology) Toran Kapoor

Gautam Buddha University

Address: D-301, Vrinda City, Greater Noida-201308, India

Mobile: +919350828430

E-mail: torantalwar@gmail.com

Assistant Professor PhD. (Statistics and Operational Research) Manisha Sharma

Gautam Buddha University

Address: 287 A, pocket C, Mayur Vihar Phase II, Delhi 110091, India

Mobile: +919871134125

E-mail:manisha@gbu.ac.in 